\title{
Effect of arc voltage, welding current and welding speed on fatigue life, impact energy and bead penetration of AA6061 joints produced by robotic MIG welding
}

\author{
H.R. Ghazvinloo ${ }^{1}$, A. Honarbakhsh-Raouf ${ }^{1}$ and N.Shadfar ${ }^{2}$ \\ ${ }^{I}$ Dept. of Materials Engineering, Semnan University, Semnan, Iran. ${ }^{2}$ Oghab Afshan Indus. and Man. Co., Semnan, Iran. \\ Hamid.Ghazvinloo@gmail.com; Ahonarbakhsh@Semnan.ac.ir; Nasim.Shadfar@oghabafshan.com
}

\begin{abstract}
Aluminum alloys forming to AA6061 have a wide range of desirable properties which are used in different industries such as aircraft industry and other aerospace structures. The effect of process parameters on fatigue life and impact energy of weld metal, and bead penetration in AA6061 joints produced by MIG robotic welding was studied in this paper. Different samples were produced by employing arc voltage of 20,23 , and $26 \mathrm{~V}$, welding current of 110,130 , and $150 \mathrm{~A}$, and welding speed of 50, 60, and $70 \mathrm{~cm} / \mathrm{min}$. After welding operations, the mechanical properties of the weld metal were evaluated by fatigue and impact testing at room temperature, and bead penetration was measured for geometrical specimens. Results were clearly illustrated when heat input increases, fatigue life of weld metal decreases whereas impact energy of weld metal increases in first and then drops significantly. A linear increase in bead penetration was observed with increasing welding current and arc voltage. The largest penetration in this study was observed for $60 \mathrm{~cm} / \mathrm{min}$ welding speed.
\end{abstract}

Keywords: MIG parameters; fatigue life; impact energy; bead penetration, welding.

\section{Introduction}

Aluminum and its alloys are used extensively in aerospace and automotive industries because of its low density and high strength to weight ratio (Bakes \& Benjamin, 1979). Heat treatable wrought aluminum-magnesium-silicon alloys conforming to AA6061 are of moderate strength and possess excellent welding characteristics over the high strength aluminum alloys (Thomas, 1991). Hence, alloys of this class are extensively employed in marine frames, pipelines, storage tanks and aircraft applications (Dawes, 1995). Fusion welding processes are widely used for fabrications in many engineering applications such as aerospace, automotive, shipbuilding industries (Gourd, 1995; Puchaicela, 1998). These welding processes are routinely used for joining structural aluminum alloys (Elangovan et al., 2009). A Metal Inert Gas (MIG) welding process consists of heating, melting and solidification of parent metals and a filler material in localized fusion zone by a transient heat source to form a joint between the parent metals (Gourd, 1995; Puchaicela, 1998). MIG welding parameters are the most important factors affecting the quality, productivity and cost of welding joint (Kim et al., 2003; Ming et al., 2003).

The present paper aims at the evaluation of fatigue life, impact energy and bead penetration of AA6061 plates obtained by employing different MIG parameters. Extensive studies have been made on fatigue and impact behavior of welded joints. For example, Cavaliere et al. (2006) researched on the effect of process parameters on fatigue behavior of AA6056 joints produced by friction stir welding. Also, Cavaliere et al. (2008) studied on the effect of friction stir welding parameters on fatigue properties of AA6082 joints. Large numbers of fatigue testing results of welded joints after ultrasonic peening treatment (UPT) were analyzed by Wang Ting et al. (2009). Lee et al. (2009) studied on effect of the weld geometry on the fatigue life of non-load-carrying fillet welded cruciform joints. Kolhe \& Datta (2007) investigated and correlated the relationship between the various parameters of SA welding and impact energy of single "V" butt joint of mild steel plate. Effect of controlled atmosphere on impact energy of MIG-MAG weldments was described by Kacar \& Kökemli (2005). Investigation into the relationship between the welding parameters and bead geometry began in the mid-1900s and regression analysis was applied to welding geometry research by Lee et al. (2000) and Raveendra \& Parmar (1987). The effect of process parameters on weld penetration in gas metal arc welding processes was studied by Karadeniz et al. (2007). However, there exists still little information regarding to the welding researches on fatigue and impact behavior, and bead penetration in AA6061 aluminum alloy welding joints, especially in MIG welding process.

\section{Materials and methods}

Due to high importance, welding joints were produced from AA6061 aluminum alloy. The ER5356 (AWS A5.10) wire electrode with $1 \mathrm{~mm}$ diameter was used as filler metal. In the present study, the consumable wire electrode was selected based on properties and characteristics of the base material, weld dimensions, and existing wire electrode inventory. The chemical composition of filler metal is given in Table 1. 
Table 1. Chemical composition of filler metal (ER5356).

\begin{tabular}{|c|c|c|c|c|}
\hline Element & $\mathbf{M g}$ & $\mathbf{M n}$ & $\mathbf{S i}$ & $\mathbf{F e}$ \\
\hline$W t .(\%)$ & 5.00 & 0.13 & 0.25 & 0.40 \\
\hline $\mathbf{A l}$ & $\mathbf{C r}$ & $\mathbf{T i}$ & $\mathbf{Z n}$ & $\mathbf{C u}$ \\
\hline Balance & 0.13 & 0.13 & 0.10 & 0.10 \\
\hline
\end{tabular}

$100 \%$ argon was used as shielding gas in welding operations. The base materials were supplied in form of plates with $\sim 2.35 \mathrm{~mm}$ and $10 \mathrm{~mm}$ thickness for experimental tests. The plates were cut into coupons with a $30^{\circ}$ bevel of each plate to provide $60^{\circ}$ groove angle for single-V-groove butt joint configuration. In order to minimize the welding distortion, the plates were located in the fixture jig before welding operations. For each test condition, the seven welding passes were used to join the base metals, and the parameters in welding seven passes in each test condition were same. The MIG welding operations in this study were performed by means of a SOS Model DR Series ARK ROBO 1500 welding robot with a working capacity of $0-600 \mathrm{~A}$ and $0-50 \mathrm{~V}$ ranges. The welding robot and its apparatus are shown in Fig. 1.

Fig.1. The welding robot and its apparatus used in this study.

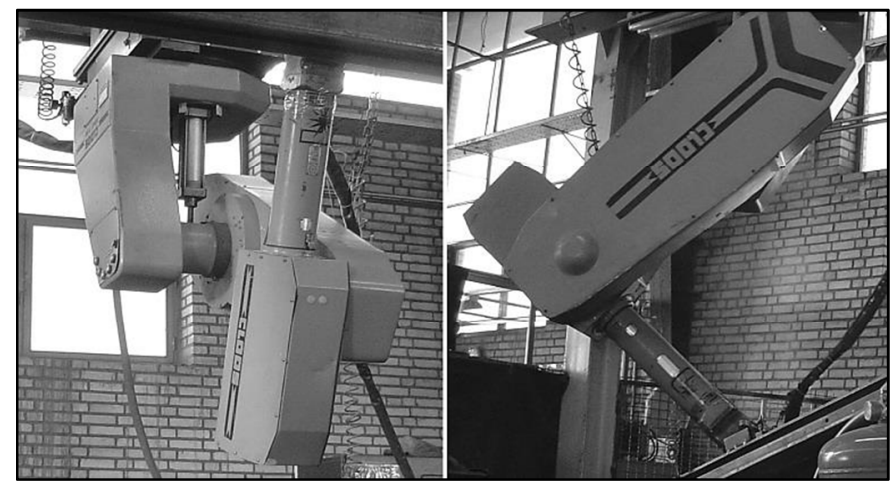

The welding characteristics of MIG process were set up according to parameters given in Table 2, and are shown in Fig.

2. The other parameters were fixed.

Table 2. Welding parameters applied in this study.

\begin{tabular}{|c|c|}
\hline Cylinder Pressure (bar) & 145 \\
\hline Cylinder Outlet Pressure (1/min) & 14 \\
\hline Nozzle Opening (mm) & 10 \\
\hline Electrode Stick Out (mm) & 19.2 \\
\hline Arc Length (mm) & 3 \\
\hline Nozzle-to-Work Distance (mm) & 20.2 \\
\hline Contact Tip-to-Work Distance (mm) & 22.2 \\
\hline Arc Voltage (V) & $20,23,26$ \\
\hline Welding Current (A) & $110,130,150$ \\
\hline
\end{tabular}

\begin{tabular}{|c|c|}
\hline Welding Speed $(\mathrm{cm} / \mathrm{min})$ & $50,60,70$ \\
\hline Wire Feeding Rate $(\mathrm{m} / \mathrm{min})$ & 8 \\
\hline Torch Angle (degree) & 5 \\
\hline Droplet Transfer & Spray Transfer Mode \\
\hline Polarity & DCEP \\
\hline
\end{tabular}

Fig.2. MIG welding parameters (Palani \& Murugan, 2006).

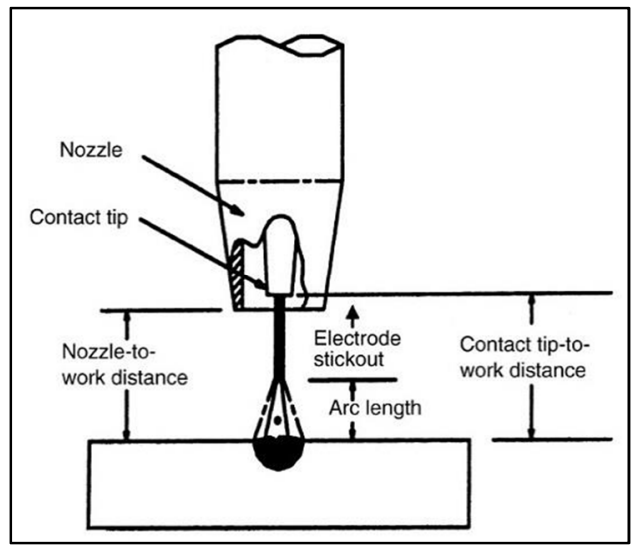

The 27 welding conditions with different arc voltage, welding current and welding speed combinations in this study are shown in Table 3. Having finished the welding process, fatigue and impact testing were carried out at room temperature in order to evaluate the fatigue life and impact energy of the weld metals produced in different welding conditions. Fatigue testing on weld metals was performed by using the ZWICK test machine under constant loading control up to $250 \mathrm{~Hz}$ sinuses wave loading. The low cycle and high cycle fatigue tests were conducted in the axial total stressamplitude control mode with a stress ratio $\left(R=\sigma_{\text {Min }} / \sigma_{\text {Max }}\right)$ equal to 0.1 , for all arc voltages, welding currents and welding speeds used in the present study. Fatigue testing specimens of $5 \mathrm{~mm}$ middle diameter and $21.27 \mathrm{~mm}$ gauge length according to DIN 50113 guidelines were extracted from the welded joints. The fatigue specimens were tested at the $180 \mathrm{MPa}$ stress range only with stress ratio of 0.1 in order to study the effect of the MIG parameters on fatigue life of the weld metals. Impact testing was performed to measure the impact energy of the weld metals. The Standard Charpy V-notch (CVN) specimens were extracted from welded joints according to ASTM E23 standard. It is shown in Fig. 3. The standard impact specimens were $55 \times 10 \times 10 \mathrm{~mm}^{3}$. A standard Charpy V-notch specimen includes a $45^{\circ} \mathrm{V}$ notch with $2 \mathrm{~mm}$ depth, and $0.25 \mathrm{~mm}$ root radius. The notch was located in center of impact specimen, and also weld metal. The Dynatup KGH impact tester was used to perform the impact testing. Dynatup is a drop weight impact test tower. Impact testing was carried out with an impact velocity of $\sim 5 \mathrm{~m} / \mathrm{s}$, and using a tup capacity equal to $\sim 44 \mathrm{kN}$. In order to study the effect of MIG process parameters on bead penetration, the specimens were cut perpendicular to weld line by using a power hacksaw. 
Then the cross-sections surfaces were machined, removed from each impurity, polished, and etched using $2 \%$ nital for measuring bead penetration. A schematic illustration of bead penetration in welding applications is shown in Fig. 4.

Table 3. The different welding conditions used in this study.

\begin{tabular}{|c|c|c|c|}
\hline $\begin{array}{c}\text { Sample } \\
\text { Number }\end{array}$ & $\begin{array}{c}\text { Welding } \\
\text { Current (A) }\end{array}$ & $\begin{array}{c}\text { Arc } \\
\text { Voltage (V) }\end{array}$ & $\begin{array}{l}\text { Welding Speed } \\
\text { (cm/min) }\end{array}$ \\
\hline 1 & \multirow{9}{*}{110} & \multirow{3}{*}{20} & 50 \\
\hline 2 & & & 60 \\
\hline 3 & & & 70 \\
\hline 4 & & \multirow{3}{*}{23} & 50 \\
\hline 5 & & & 60 \\
\hline 6 & & & 70 \\
\hline 7 & & \multirow{3}{*}{26} & 50 \\
\hline 8 & & & 60 \\
\hline 9 & & & 70 \\
\hline 10 & \multirow{9}{*}{130} & \multirow{3}{*}{20} & 50 \\
\hline 11 & & & 60 \\
\hline 12 & & & 70 \\
\hline 13 & & \multirow{3}{*}{23} & 50 \\
\hline 14 & & & 60 \\
\hline 15 & & & 70 \\
\hline 16 & & \multirow{3}{*}{26} & 50 \\
\hline 17 & & & 60 \\
\hline 18 & & & 70 \\
\hline 19 & \multirow{9}{*}{150} & \multirow{3}{*}{20} & 50 \\
\hline 20 & & & 60 \\
\hline 21 & & & 70 \\
\hline 22 & & \multirow{3}{*}{23} & 50 \\
\hline 23 & & & 60 \\
\hline 24 & & & 70 \\
\hline 25 & & \multirow{3}{*}{26} & 50 \\
\hline 26 & & & 60 \\
\hline 27 & & & 70 \\
\hline
\end{tabular}

Fig.3. Preparation of fatigue and impact specimens from welding joints

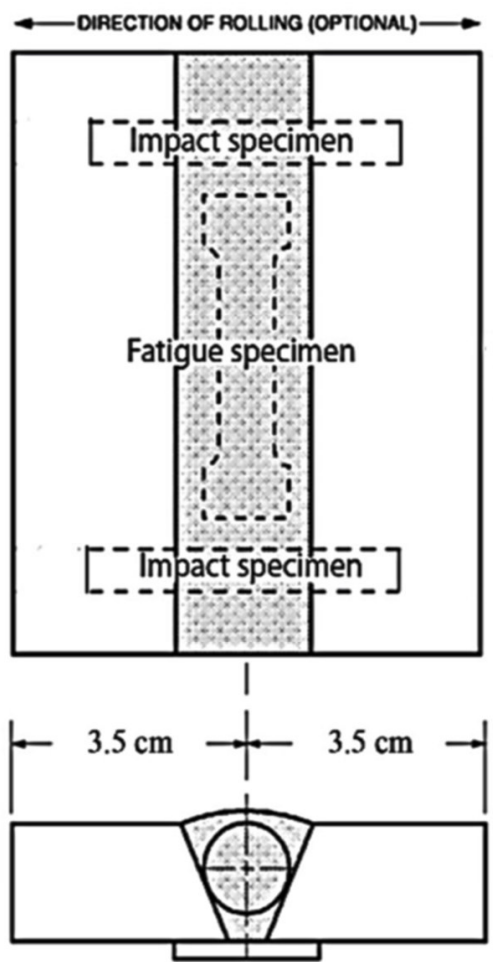

Fig.4. A schematic illustration of bead penetration (Kim et al., 2003)

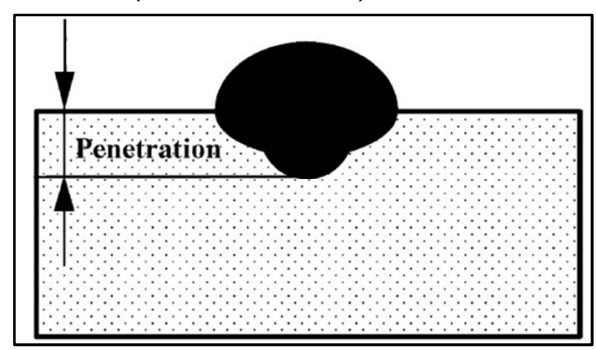

\section{Results and discussion}

The 27 welding operations with different welding current, arc voltage and welding speed combinations were performed. The results of this study as a function of the welding parameters are summarized in Table 4.

Table 4. The welding heat input, weld metal mechanical properties, bead penetration for different welding conditions.

\begin{tabular}{|c|c|c|c|c|}
\hline $\begin{array}{c}\text { Sample } \\
\text { Number }\end{array}$ & $\begin{array}{c}\text { Heat } \\
\text { Input } \\
\mathbf{( J / m m )}\end{array}$ & $\begin{array}{c}\text { Cycles } \\
\text { to } \\
\text { Failure } \\
\text { (Cycles) }\end{array}$ & $\begin{array}{c}\text { Impact } \\
\text { Energy } \\
\mathbf{( J )}\end{array}$ & $\begin{array}{c}\text { Bead } \\
\text { (metration }\end{array}$ \\
\hline 1 & 264.00 & 221 & 83.91 & 2.411 \\
\hline 2 & 219.96 & 360 & 67.37 & 2.464 \\
\hline 3 & 188.58 & 476 & 47.71 & 2.310 \\
\hline 4 & 303.60 & 198 & 91.27 & 2.571 \\
\hline 5 & 252.96 & 331 & 73.75 & 2.612 \\
\hline 6 & 216.84 & 463 & 55.00 & 2.511 \\
\hline 7 & 343.20 & 161 & 91.25 & 2.599 \\
\hline 8 & 285.96 & 317 & 83.93 & 2.634 \\
\hline 9 & 245.10 & 429 & 71.60 & 2.541 \\
\hline 10 & 312.00 & 190 & 94.18 & 2.781 \\
\hline 11 & 259.98 & 325 & 83.01 & 2.872 \\
\hline 12 & 222.84 & 439 & 67.63 & 2.741 \\
\hline 13 & 358.80 & 157 & 81.41 & 2.860 \\
\hline 14 & 298.98 & 296 & 90.55 & 2.932 \\
\hline 15 & 256.26 & 408 & 77.21 & 2.802 \\
\hline 16 & 405.60 & 101 & 63.25 & 2.941 \\
\hline 17 & 337.98 & 264 & 94.32 & 2.970 \\
\hline 18 & 289.68 & 372 & 84.62 & 2.872 \\
\hline 19 & 360.00 & 136 & 77.84 & 2.983 \\
\hline 20 & 300.00 & 272 & 91.01 & 3.020 \\
\hline 21 & 257.10 & 390 & 78.68 & 2.911 \\
\hline 22 & 414.00 & 98 & 61.17 & 3.078 \\
\hline 23 & 345.00 & 258 & 85.65 & 3.101 \\
\hline 24 & 295.68 & 366 & 88.61 & 3.001 \\
\hline 25 & 468.00 & 85 & 58.64 & 3.150 \\
\hline 26 & 390.00 & 246 & 71.91 & 3.202 \\
\hline 27 & 334.26 & 353 & 93.65 & 3.120 \\
\hline
\end{tabular}




\subsection{Effect of welding parameters on fatigue life}

The correlations between the welding parameters and fatigue life are shown in Figs. 5-7. From the results, increasing arc voltage from 20 to $26 \mathrm{~V}$, and welding current from 110 to 150 A decreased the fatigue life of weld metal but fatigue life gradually increased with increasing welding speed from 50 to $70 \mathrm{~cm} / \mathrm{min}$. In Figs. 5-7, the welding speed was fixed on 50, 60 and $70 \mathrm{~cm} / \mathrm{min}$ and the maximum values for fatigue life were obtained as 221, 360 and 476 cycles, respectively. The maximum values of fatigue life were obtained in $\mathrm{I}=110 \mathrm{~A}$ and $\mathrm{V}=20 \mathrm{~V}$ conditions. The changes in fatigue life of weld metal can be due to the microstructural changes in weld zone. According to the following function, the change in welding parameters results in the variation in welding heat input (Funderburk, 1999):

$$
\begin{aligned}
& H=(60 E I) /(1000 S) \\
& \mathrm{H}=\operatorname{Heat} \text { Input }(\mathrm{kJ} / \mathrm{mm}) \\
& \mathrm{E}=\operatorname{Arc} \text { Voltage }(\mathrm{V}) \\
& \mathrm{I}=\text { Welding Current }(\mathrm{A}) \\
& \mathrm{S}=\text { Welding Speed }(\mathrm{mm} / \mathrm{min})
\end{aligned}
$$

Fig.5. Fatigue life vs. welding current diagram for $50 \mathrm{~cm} / \mathrm{min}$ constant welding speed

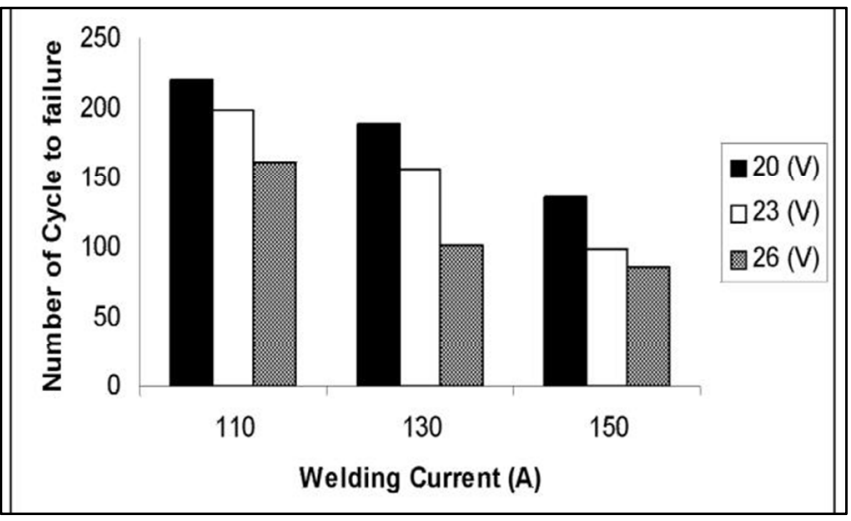

Fig.6. Fatigue life vs. welding current diagram for $60 \mathrm{~cm} / \mathrm{min}$ constant welding speed

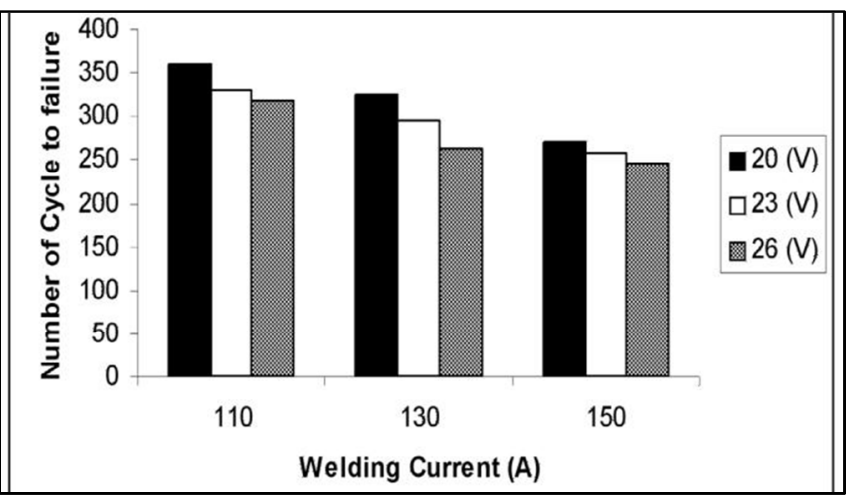

Fig.7. Fatigue life vs. welding current diagram for $70 \mathrm{~cm} / \mathrm{min}$ constant welding speed

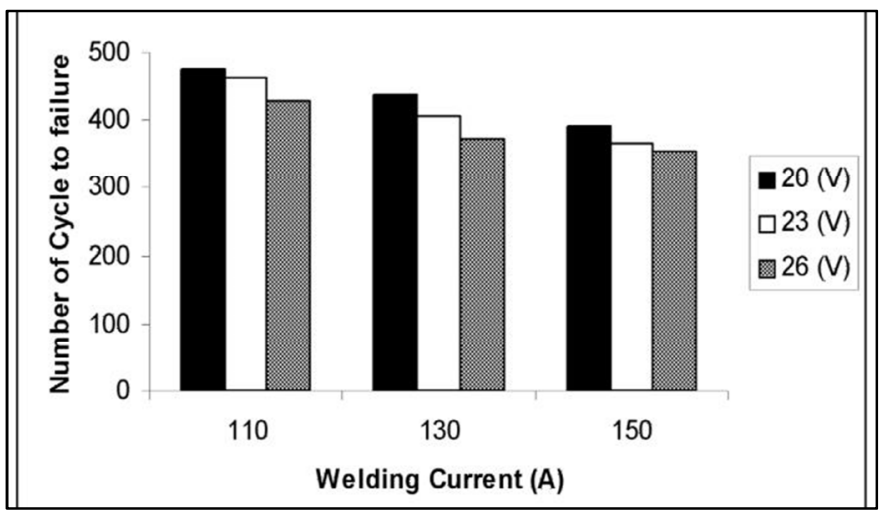

Varying in heat input typically affect the microstructure and mechanical properties of weld. The amount of heat input influences on cooling rate of the weld. The following proportionality function shows the relationship between preheat temperature, heat input and cooling rate of weld. Welding heat input and preheat temperature interact with others such as material thickness, specific heat, density and thermal conductivity to influence the cooling rate (Funderburk, 1999).

$$
\begin{aligned}
& R \propto 1 /\left(T_{0} \cdot H\right) \\
& \mathrm{R}=\text { Cooling Rate }\left({ }^{\circ} \mathrm{C} / \mathrm{sec}\right) \\
& \mathrm{T}_{0}=\text { Preheat Temperature }\left({ }^{\circ} \mathrm{C}\right) \\
& \mathrm{H}=\text { Heat Input }(\mathrm{kJ} / \mathrm{mm})
\end{aligned}
$$

The cooling rate is a primary factor that determines the final microstructure and mechanical properties of the weld metal. When the heat input increases, the cooling rate decreases for a given weld metal (Funderburk, 1999) and increases the coarsening of the microstructure of weld. It is shown in Fig. 8.

\subsection{Effect of welding parameters on impact energy}

As shown on Table 4, as heat input increased from 188.58 to $337.98 \mathrm{~J} / \mathrm{mm}$, the impact energy of weld metal increased from 47.71 to $94.32 \mathrm{~J}$. But with further increasing heat input from 337.98 to $468 \mathrm{~J} / \mathrm{mm}$, impact energy of the weld metal dropped significantly (Fig. 9). It seems that the changes in impact energy of the weld metal is not just tied to the heat input; it is also significantly influenced by the weld bead size. For example, the following function shows approximately relationship between heat input and fillet weld leg size (Miller \& Funderburk, 1998):

$$
\begin{aligned}
& W=(H / 500)^{1 / 2} \\
& \mathrm{~W}=\text { Fillet Weld Leg Size }(\text { in }) \\
& \mathrm{H}=\text { Heat Input }(\mathrm{kJ} / \mathrm{in})
\end{aligned}
$$

As the weld bead size increases, which is corresponds to a higher heat input, the impact energy tends to decrease. In multiple-pass welds, a portion of the previous weld passes is refined, and the toughness improved, as the heat from each pass tempers the weld metals below it. If the weld beads are smaller, 
more grain refinement occurs, resulting in better notch toughness, all other factors being even (Funderburk, 1999).

Fig.8. Microstructure of weld for (a) low heat input

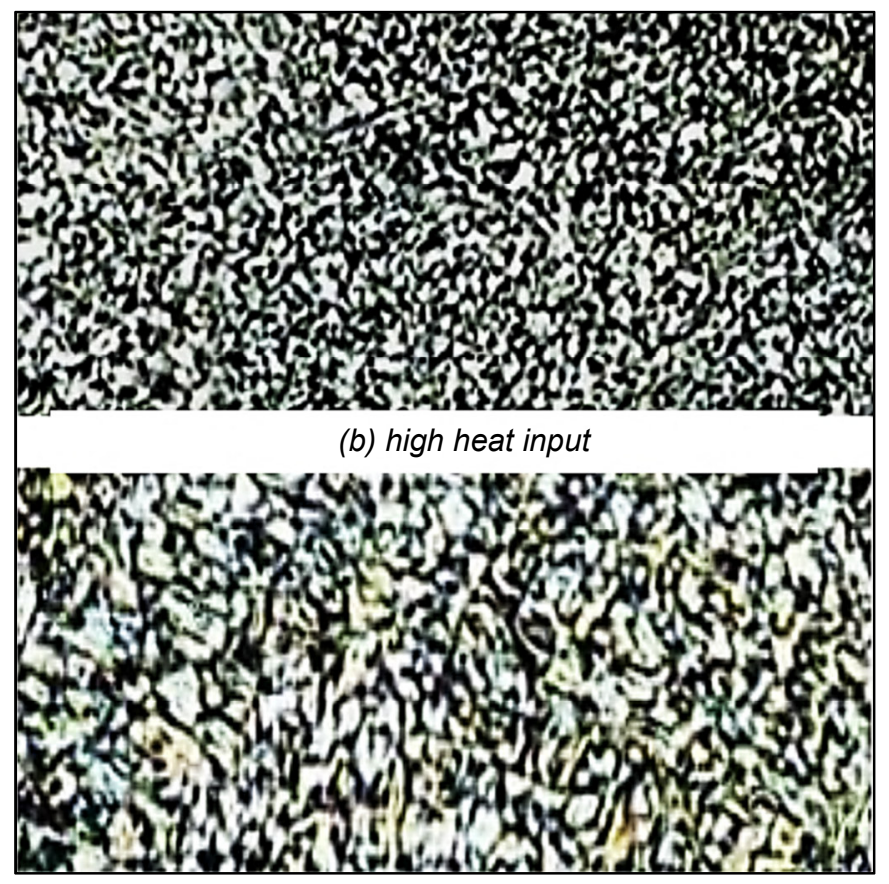

Fig.9. Impact energy of the weld metal vs. welding heat input.

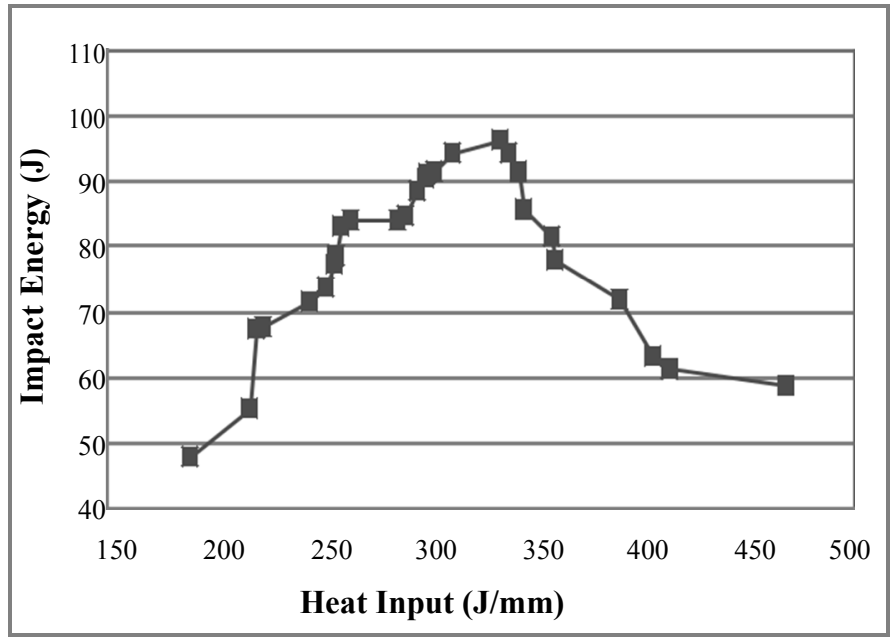

\subsection{Effect of welding parameters on penetration}

The 27 welding samples for determining the bead penetration in different welding conditions are shown in Fig. 10. In Figs. 11-13, the welding speed was fixed on 50, 60, and $70 \mathrm{~cm} / \mathrm{min}$ respectively, and the change in bead penetration was drawn vs. welding current for 20,23 , and $26 \mathrm{~V}$ arc voltage. A linear increase in bead penetration was observed with increasing welding current and arc voltage in different welding speeds. In Fig. 11, the welding speed was fixed on $50 \mathrm{~cm} / \mathrm{min}$. The largest penetration value of $3.150 \mathrm{~mm}$ was obtained in $150 \mathrm{~A}$ and $26 \mathrm{~V}$ condition, while the lowest penetration value was $2.411 \mathrm{~mm}$ in $110 \mathrm{~A}$ and $20 \mathrm{~V}$ condition.
In Fig. 12, the welding speed was fixed on $60 \mathrm{~cm} / \mathrm{min}$. The largest penetration value of $3.202 \mathrm{~mm}$ was obtained in $150 \mathrm{~A}$ and $26 \mathrm{~V}$ condition, while the lowest penetration value was $2.464 \mathrm{~mm}$ in $110 \mathrm{~A}$ and $20 \mathrm{~V}$ condition. In Fig. 13, the welding speed was fixed on $70 \mathrm{~cm} / \mathrm{min}$. The largest penetration value of $3.120 \mathrm{~mm}$ was obtained in $150 \mathrm{~A}$ and $26 \mathrm{~V}$ condition, and the lowest penetration value was $2.310 \mathrm{~mm}$ in $110 \mathrm{~A}$ and $20 \mathrm{~V}$ condition. The bead penetration increased with increasing welding speed from 50 to $60 \mathrm{~cm} / \mathrm{min}$. The $60 \mathrm{~cm} / \mathrm{min}$ was the optimum value of welding speed to obtain maximum bead penetration. Bead penetration began to decrease in welding speeds higher than $60 \mathrm{~cm} / \mathrm{min}$. These results were similar to the results of previous literature (Tülbentci, 1990; Ates \& Türker, 1999; Karadeniz et al., 2007).

Fig.10. The 27 welding samples for determining the bead penetration in different welding conditions.

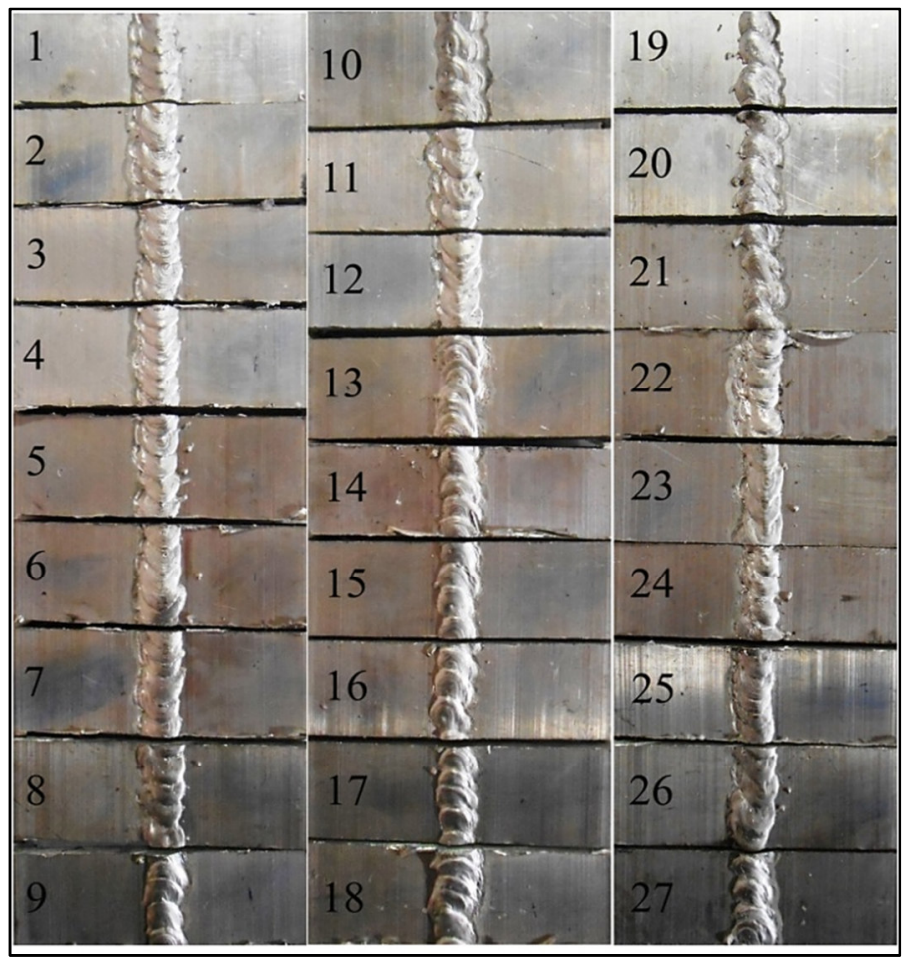

Fig.11. Penetration vs. welding current for $50 \mathrm{~cm} / \mathrm{min}$ welding speed.

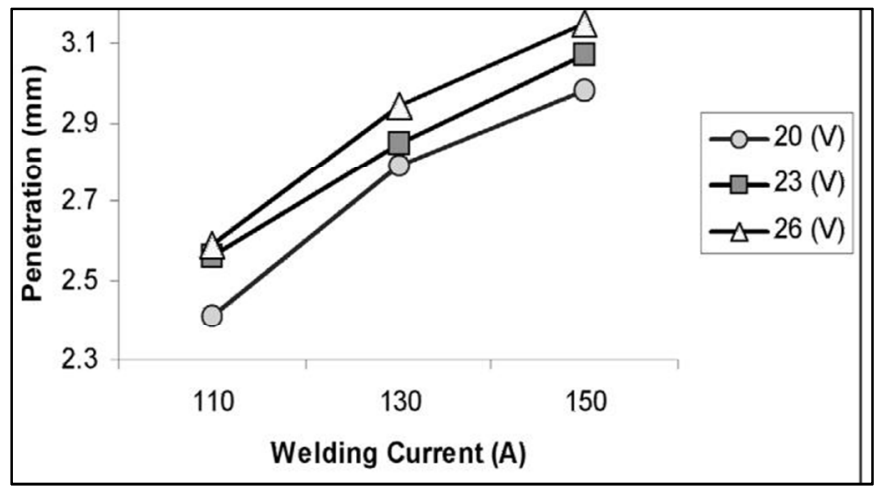


Fig.12. Penetration vs. welding current for $60 \mathrm{~cm} / \mathrm{min}$ welding speed.

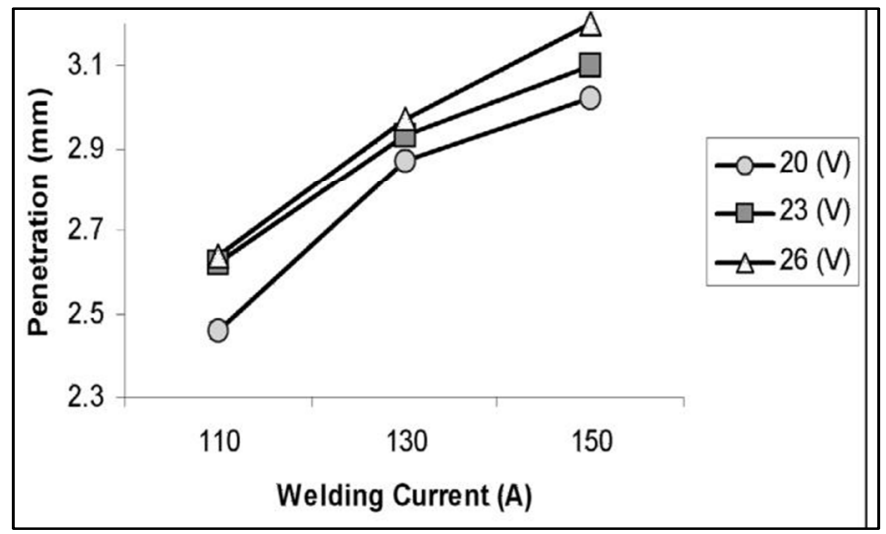

Fig.13. Penetration vs. welding current for $70 \mathrm{~cm} / \mathrm{min}$ welding speed.

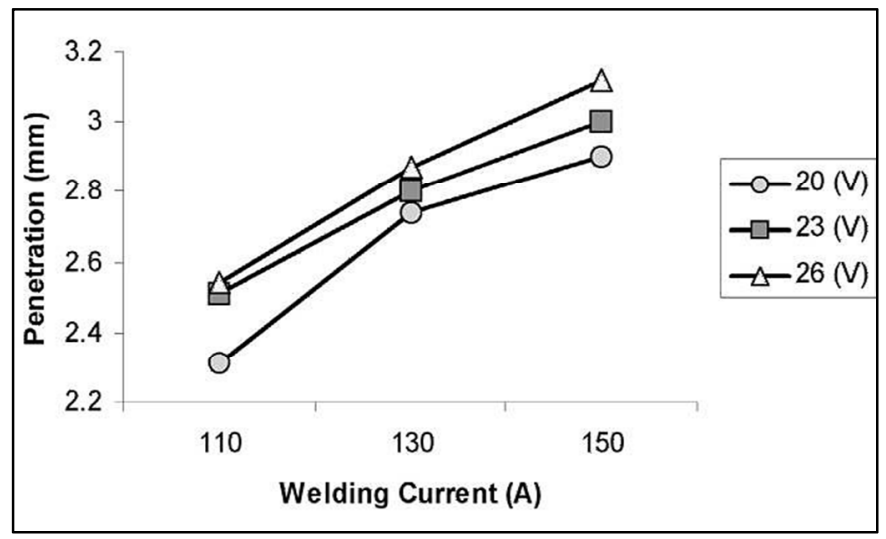

\section{Conclusions}

According to the results obtained from robotic MIG welding applied to AA6061 aluminum alloy plates with $\sim 2.35$ and $10 \mathrm{~mm}$ thickness:

The fatigue life of the weld metal decreased clearly with increasing arc voltage between 20 and $26 \mathrm{~V}$ and welding current between 110 and $150 \mathrm{~A}$, whereas the effect of welding speed on fatigue life was reversed to other parameters. When welding speed increased, fatigue life of the weld metal also increased. Welding heat input increased by increasing arc voltage, welding current and decreasing welding speed. Impact energy of the weld metal increased slightly and then dropped significantly as welding heat input increased. The maximum value of impact energy for weld metal in the present study was $94.32 \mathrm{~J}$ that was obtained for $\mathrm{I}=130 \mathrm{~A}, \mathrm{~V}=26 \mathrm{~V}$, and $\mathrm{S}=60 \mathrm{~cm} / \mathrm{min}$ condition. The bead penetration increased linearly with increasing welding current between 110 and $150 \mathrm{~A}$. In addition to the welding current, increasing arc voltage between 20 and $26 \mathrm{~V}$ also increased the bead penetration. However, its effect was not as much as welding current. When the welding speed was taken as a parameter, the largest bead penetration was obtained in $60 \mathrm{~cm} / \mathrm{min}$. The bead penetration increased with increasing welding speed between 50 and $60 \mathrm{~cm} / \mathrm{min}$, and then its value decreased after this point. The largest value of bead penetration in this study was $3.202 \mathrm{~mm}$ which was obtained in $150 \mathrm{~A}$, $26 \mathrm{~V}$, and $60 \mathrm{~cm} / \mathrm{min}$ condition. The effect of welding current on bead penetration was greater than arc voltage and welding speed effect.

\section{Acknowledgements}

The authors would like to thank Managing Director of Industrial \& Manufacturing Company of Oghab Afshan for the financial support and Semnan University for all the facilities.

\section{References}

1. Ates $H$ and Türker M (1999) Determination of penetration with various welding parameters of electrical arc and GMA welding. J. Gazi. Univ. 12, [in Turkish].

2. Bakes H and Benjamin D (1979) Metals Handbook, Volume. 2. (Ed.) Kirkpatrick CW, ASM, Metals Park, OH. pp: 3-23.

3. Cavaliere P, Campanile G, Panella F and Squillace A (2006) Effect of welding parameters on mechanical and microstructural properties of AA6056 joints produced by friction stir welding. J. Mater. Process. Technol. 180, 263270 .

4. Cavaliere P, Squillace A and Panella F (2008) Effect of welding parameters on mechanical and microstructural properties of AA6082 joints produced by friction stir welding. J. Mater. Process. Technol. 200, 364-372.

5. Dawes CJ (1995) An introduction to friction stir welding and its development. J. Weld Met. Fabric., 6-12.

6. Elangovan K, Balasubramanian V and Babu S (2009) Predicting tensile strength of friction stir welded AA6061 aluminum alloy joints by a mathematical model. J. Mater. \& Des. 30, 188-193.

7. Funderburk RS (1999) Key Concepts in Welding Engineering. Welding Innovation, Vol. XVI, No. 1.

8. Gourd LM (1995) Principles of Welding Technology, 3rd ed. Edward Arnold.

9. Kacar R and Kökemli K (2005) Effect of controlled atmosphere on the mig-mag arc weldment properties. J. Mater. \& Des. 26, 508-516.

10. Karadeniz E, Ozsarac U and Yildiz C (2007) The effect of process parameters on penetration in gas metal arc welding processes. J. Mater. \& Des. 28, 649-656.

11. Kim IS, Sona JS, Kim IG, Kim JY and Kim OS (2003) A study on relationship between process variables and bead penetration for robotic $\mathrm{CO}_{2}$ arc welding. J. Mater. Process. Technol. 136, 139-145.

12. Kolhea KP and Dattab CK (2007) Prediction of microstructure and mechanical properties of multipass SAW. J. Mater. Process. Technol. 11029, 1-9.

13. Lee CH, Chang KH, Jang GC and Lee CY (2009) Effect of weld geometry on the fatigue life of non-load-carrying fillet welded cruciform joints. J. Eng. Fail. Anal. 16, 849-855.

14. Lee JI and KW Um (2000) A prediction of welding process parameters by prediction of back-bead geometry. J. Mater. Process. Technol. 108, 106-13.

15. Miller DK and Funderburk RS (1998) Reviewing and Approving Welding Procedure Specifications. The National Steel Construction Conference Proceedings. New Orleans, AISC. 
16. Ming $\mathrm{HG}$ and et al. (2003) Acquisition and pattern recognition of spectrum information of welding metal transfer. J. Mater. \& Des. 24, 699-703.

17. Palani PK and Murugan N (2006) Selection of parameters of pulsed current gas metal arc welding. $J$. Mater. Process. Technol. 172, 1-10.

18. Puchaicela J (1998) Control of distortion of welded steel structures. J. Welding. 77, 49-52.

19. Raveendra J and Parmar RS (1987) Mathematical models to predict weld bead geometry for flux cored arc welding. J. Met. Construct. 19, 31-5.

20. Thomas WM (1991) Friction stir welding. Int. Patent Appl. No. PCT/GB92/02203 and GB Patent Application No. 9125978.8. U.S. Patent No. 5,460,317.

21. Ting W, Dongpo W, Lixing H and Yufeng Z (2009) Discussion on fatigue design of welded joints enhanced by ultrasonic peening treatment (UPT). J. Fatigue. 31, 644-650.

22. Tülbentci K (1990) MIG-MAG arc welding, Gedik Welding Co. Press, Istanbul, [in Turkish]. 